\title{
Competing Desires and Realities: Language Policies in the French-Language Classroom
}

\author{
Angela Giovanangeli, University of Technology, Sydney
}

One of the first concepts I teach a beginner level French language class, in an Australian university context, is that nouns in French have genders: they are either masculine or feminine. Fairly early on in the semester we also look at professional titles. In the first lessons students learn that despite being a woman, I am le professeur, which is the masculine noun for teacher. Yet, while the dictionary confirms this noun is masculine, in everyday language the female version, la professeure, is used by the French to make the distinction between a female and male teacher. Other professional nouns like $u n$ écrivain (a writer), un auteur (an author), un ingénieur (an engineer) share similar fates: in popular idiom the female nouns une écrivaine, une auteure, une ingénieure refer to a female writer, author or engineer. As with le professeur, in grammar books or dictionaries written and published in France, only the masculine appears.

As a language teacher I thus have to explain to students that the French sometimes use words that reflect female professional titles even though they are not officially acknowledged in the formal references of the French language. The same can be said of words that are borrowed from other languages, English particularly. I have come across structures spoken by the French like j'ai booké une chambre d'hôtel (I have booked a hotel room). The verb booker, an obvious English borrowing, replaces the French verb réserver. Officially, the verb booker does not exist in French. Similar examples, $j$ 'ai forwardé ton email, and, j'ai emailé, deploy the English words to forward and to email. The use of these words, however, is frowned upon by French language authorities. 
In the French-language classroom students are confronted with the reality of the gap between unofficial terms and idiomatic usages on the one hand, and on the other, the desires of language authorities in France. Those authorities strive to maintain terms and grammatical structures that do not always reflect the changes that language undergoes. This is clearly a common phenomenon in all languages. In France, however, specific French language policies determine how the language should be spoken. Discussing these concepts in the classroom creates, in a sense, a type of space where the official and unofficial converge uneasily and where students are asked to make choices on how they learn and speak the French language, and why.

This article examines some of the policies and agencies created in France over recent years that affect the French language and how it is taught. Surprisingly little research has been undertaken on the consequences of French language policies for the teaching of French as a foreign language in classrooms, either in English speaking countries like Australia, or in France. Among the existing scholarship, three trends are evident. Some critics examine language policies in France from a social and political point of view (Adamson 2007; De Certeau et al 2002), others discuss the historical place of French in Europe (Réau 1938), while the third trend analyses the relations between the French language and its foreign rivals (Walter 2001; Gilder 1993). In part addressing the dearth of studies on language teaching and language policy, in this essay I argue that a space is created within the language classroom that requires a negotiated compromise between the language policies of the French government and the idiomatic realities of contemporary French society. Due to my location, I also attend to the more specific question of how French language policies affect French language classes in an Australian university in Sydney. My discussion here is not exhaustive; but it does present some of the significant challenges I encounter as a language teacher of French contemplating how French language policies affect the teaching of the French language elsewhere in the world. This article, then, refers to observations and reflections of my experiences in the language classroom over many years and is shaped by informal discussions I have had with colleagues involved in teaching French.

\section{French language policies}

French language policy has historically centred on the ways by which French can be identified as a dominant and influential language, both within France and internationally. 
Since the Middle Ages, French political figures have encouraged the promotion of French by allowing the French language to serve as a political tool. On a national level, French has been used to centralise political power through the creation of an official language and the suppression of local and regional linguistic expression. Beyond France's borders, French has been imposed on conquered peoples, the language thus serving as a mode of domination in the process of colonisation. Language was also used to promote France's international status throughout Europe when French became a diplomatic language in the 1700s. Today some leading French politicians and thinkers (Magnant 2009; Lang 2000) have inherited the long-standing historical concern to protect French within France's borders, and beyond France as an international language. Laws and debates continue on how the French language should be spoken. However, the reality of the situation is that, on the one hand, laws exist that identify how French is to be written and spoken; but on the other hand, French usage in France does not conform to rules set in place by state and linguistic apparatuses. This conflicted situation has implications for the way the French language is taught in French language classrooms across the world.

In France language policies have centred on regulations and associations that aim to increase and protect the use of French in everyday society. Researchers of language policies are quick to point out that language policies in France stem as far back as 1539, when François $1^{\mathrm{er}}$ issued an edict known as the Ordonnance de Villers-Cotterêts, requesting the use of French instead of Latin in legal judgements (Adamson 2007: 2). In 1635 the Académie française was created to fix the rules of correct language usage and to protect the French language from outside influences. This process further strengthened the notion that the language required protection and codification. ${ }^{1}$ In addition, the relationship between language and political power was a motivating factor for the implementation of language policies. In the hands of the monarchy and aristocracy, the French language was a tool that enabled the centralisation of national power around court life. By the early 1700s speakers of the French language were able to pride themselves on seeing French established as the European language of diplomacy, a key moment in the evolution of the idea that French was a universal language. From the 1714 Treaty of Rastadt, which recognised French as the official

\footnotetext{
${ }^{1}$ According to Adamson (2007: 2-4) the codification of the French language in the 1700s was considered a way to protect French from the rising influence of the Italian language in French court life that had begun in the high Renaissance of the 1600s.
} 
language of diplomacy in Europe, until the Treaty of Versailles in 1919, this diplomatic status was maintained.

\section{Desires of universality}

The preoccupation with the French language and its universality, Adamson reminds us, still exists today (2007: 9). In his essay on the French language, Gilder explains that a language's universality is measured by the number of people who speak it. Whilst Gilder laments the decline in the number of French speakers in the world today (only three percent of the planet) (1993: 19), figures on the website of the French Ministry for Foreign Affairs paint a contrasting, positive picture. In 2007, according to this website, there were 200 million French speakers in the world. This number jumped to 264 million speakers if people in contact with the French language, such as learners and residents of partly francophone countries, are taken into consideration. This expanded remit, according to the website, accounted in 2007 for eleven percent of the world population. The website also claimed in that year that 'French has never been spoken by so many around the world. It counts among the planet's great languages' (Ministère des Affaires Etrangères 2007). These figures, however, do not take into consideration the nuances that exist between the different 'types' of French spoken around the world. For example, the French language spoken in former French colonies like Senegal has its own particular structures and vocabulary not found in the French spoken in France.

The underlying motives and reasons for such concern over the total number of French speakers have been clearly documented by researchers and reinforced by political figures, and are linked to the close parallel between language and national identity in France as well as the historical connection between language and cultural and political hegemony. France in the twentieth and twenty-first centuries inherited a language ideology based on the promotion and the defence of the French language. This ideology was, and remains, supported by the number of government associations created to defend French, such as the Office de la langue française (1937, Office of the French Language), Office du vocabulaire français (1957, Office for French Vocabulary), Commission de terminologie pour l'enrichissement de la langue française (1972, Terminology Commission for the Enrichment of the French Language) and the Commission générale de terminologie et néologie (1996, General Commission for Terminology and Neologisms), to name a few. 
These institutions were accompanied and bolstered by government legislation, such as the 1994 Toubon law restricting the use of foreign terms in the French language and establishing quotas on the number of French songs to be played on French radio stations. Some prominent French institutions have been known to impose the use of English in their internal communications or discussions, only to have that policy contested by government officials. For example, the Institut national de la santé et de la recherche médicale (ISERM, National Institute for Health and Medical Research), stipulated in 2005 that English was to be used in certain domains within the institution. This decision was disputed by two French unions, and a court order in 2008 ruled that ISERM could not legally impose on its employees the sole use of English.

With regard to the language teaching context and my personal experience teaching French in an English-speaking country, two language matters that are not only intriguing, but important in the establishment of a French language space of learning, are the use of English words in French and the feminisation of professional titles in France. These two trends have been widely covered by researchers and political thinkers and are the subject of many controversial debates. Walter (2001) and Sonntag (2003) have covered the English debate, while Brick and Wills (1994, 2002), Vandendorpe (1995), Rey-Debove (1999), Houdebine-Gravaud (1999), and Yaguello (2002) examine the feminisation of job titles. I examine these two debates from a language teaching perspective in more detail later in this article. Preceding that discussion it is necessary to consider how the extensive number of agencies concerned with the way the French language is constructed, affect French public attitudes towards the use of English in the French language and the feminisation of professional titles.

\section{French attitudes towards the French language}

In the context of the English versus French debate, evidence of how language policies define public behaviour are cited in 'Chirac contre l'anglais,' a 2006 article by Charles Bremner, Paris correspondent for The Times. Here Bremner describes how former French president Jacques Chirac stormed out of a European summit in 2006 because a French delegate had addressed a session in English. Bremner points out that this incident is 'a fine example of France's Quixotic battle against reality,' given that the 'resistance to English has long ago faded among the younger generation and the world of business and technology' (2006). Examples such as this highlight the tension 
between the desire to preserve French language as unsullied, intact and internationally important and the realties of a social epoch that tolerates the use of English in the political, economic and cultural spheres. Despite the increasing acknowledgement by many French speakers of these realities, a more recent controversy over the French contribution to the 2008 Eurovision song contest confirms that those tensions remain highly charged. Singer Sébastien Tellier represented France with his song Divine, which was written almost entirely in English, thus entangling himself in a debate over his preferred choice of language usage. The conservative rightwing politician FrançoisMichel Gonnot, from the Union pour un Mouvement Populaire (UMP, Union for a Popular Movement), expressed his outrage in the media that a song in English was going to represent France. He consequently asked the French minister for Culture, Christine Albanel, 'to explain the decision to parliament,' given the fact that 'this choice shocks a lot of citizens who do not understand why France is thus giving up the defence of its language before hundreds of millions of television viewers' (Bremner 2008).

While the above examples reflect deep-seated antipathy toward the use of English in place of French, that attitude is paralleled by wide concerns about the introduction and use of English words in the French language. In his 1993 study, Et si l'on parlait français? Essai sur une langue universelle (What if we spoke French? Essay on a universal language), Gilder took a pessimistic view by identifying a growing degradation in French language usage. He bemoaned the increasing use of English words as brand names (for example, Renault's Scenic, or the cigarette brands Blueway and News) (1993: 31), and the trend toward English pronunciation of identically written French words (for example, 'management,' 'bacon' and 'challenger') (69). Gilder closes his study by providing a glossary of common English words used in French that should be replaced by their French equivalents (for example, camisette for t-shirt). Gilder is emblematic of the many defenders of the French language who provide unrealistic lists as a way of trying to keep English borrowings out of the French language. The reality is that English terms continue to be borrowed and used in French. Language students of the French language, whatever their background and the country in which they are studying, often have questions about which English words exist in French and how they are to be pronounced. Regardless of the fact that defenders of the French language would like to maintain the purity of the language, students of French across the globe do require a space in which to discuss these linguistic realities. 
The issue of the feminisation of professional titles in French, like the use of English loan words, has also sparked charge debates. Language use has been a significant target in the fight for the equal treatment of women, as is evident in the ongoing discussions on the need to reform professional titles in France. Since the late 1990s, French women in politically influential positions have been vocal about how they would like professional titles to be formed. For example, women in the ministry of the Socialist Prime Minister Lionel Jospin's government in the 1990s, frustrated by the male title of Minister, made requests to be officially addressed using a female equivalent. Jospin published a circular in 1998 in favour of the feminisation of professional titles, and supporting the change of the masculine word for le Ministre (Minister) to the feminine la Ministre. This action was regarded at the time as a way of acknowledging the equal treatment of women in the workplace and also of avoiding possible misunderstandings and grammatical complications when referring to women in the masculine.

Indeed, in her article 'Language Policy and Gender Issues in Contemporary France,' Conrick highlights how 'the gender of individual terms affects other grammatical features of sentences or larger blocks of language' (2002: 215). She explains that this occurs when 'the grammatical gender of a term may be at odds with a female referent' (215). Conrick provides numerous examples of professional titles that lack female equivalents, which consequently pose problems for speakers when 'trying to 'fit' a female referent into a grammatically masculine category' (215). For example 'Nous aimons ce professeur, mais elle va nous quitter' (We like this teacher, but she is leaving us), creates grammatical awkwardness given that the noun teacher (un professeur) is masculine and the pronoun she (elle) is feminine. This example generates another aspect of the language debate that Brick and Wilks (1994) point out in their work on the feminisation of professional political titles. Noting that a 1977 decree allowed the use of a female pronoun to refer to a masculine noun, Brick and Wilks question why it is possible to legitimise changes in the use of the pronoun but not permit the feminisation of the noun (1994: 237). Another example of grammatical confusion created by masculine professional titles is the sentence: 'Un pompier a accouché la semaine dernière' (A firefighter gave birth last week). The use of the masculine title for firefighter (un pompier) thus gives the impression that a man has given birth (Conrick 2002: 216). Brick and Wilks also discuss how in the early 1990s the French media struggled to construct sentences dealing with then Prime Minister Edith Cresson's term 
in power. The media often had to juggle the masculine noun for prime minister (le premier ministre) with adjectives in the feminine, as this sentence illustrates: 'entretien du premier minister, vêtue ... d'une veste noire (interview with the Prime Minister, dressed ... in a black jacket). Here the media chose to use the masculine title with the feminine adjective vêtue, thus defying what is considered correct grammatical agreement (Brick \& Wilks 1994: 237).

In and since the 1990s, guidelines recommending female equivalents of masculine titles have been created in France. For example, the 1999 guide Femme j'écris ton nom. Guide d'aide à la féminisation des noms de métiers, titres, grades et fonctions (Woman I write your name. Guidelines to feminine equivalents of professional titles, positions and ranks) prepared by the Institut national de la langue française (National Institute of the French Language ), proposed feminine equivalents to many male occupational titles. This guide was circulated in government ministries, including the Ministry for Education, to help employees find solutions to grammatical ambiguities in French. The guide is, as its title attests, just a set of guidelines, and official changes to the language have not been made. On the contrary, the Académie française, which regulates the use of the French language, has opposed the feminisation of titles. It has justified this in the media by declaring that such feminisation would lead to the creation of ridiculous female equivalents, and reiterating that the French masculine has the capacity of relating to both genders. Houdebine-Gravaud, however, describes the negative and purist reactions of certain French speakers as verging on the hysterical when it comes to questions of the feminisation and modification of professional titles (HoudebineGravaud 1999: 46). These attitudes, it must be noted, reflect the contemporary situation in France. Other French-speaking countries like Canada and Belgium have been much more willing to modernise the French language in the face of social and cultural change (Conrick 2002: 212). Many French Canadian dictionaries, for example, include both masculine and feminine forms of professional titles, and job advertisements in Canada also address both genders.

\section{The French-language learning classroom}

What do these policies mean in the context of the French-language classroom in a country such as Australia? A brief description of the university context in which I work is helpful here for understanding the impact that French policies may have on language 
teaching and learning experiences outside France. Presently I teach in the French Language and Culture program offered as part of an International Studies degree program at an Australian university. The International Studies program offers classes in French from beginner to advanced levels, either to students studying French as a compulsory part of their International Studies degree, or to free elective students. Alongside French, Spanish, Italian, German, Chinese and Japanese are also taught. Students come from a range of disciplines-Science, Engineering, IT, Nursing, Law, Design and Architecture, Education, Communication, and Business, all in combination with International Studies - and are concentrated in the beginner or intermediate levels. They may have different linguistic backgrounds, many are bilingual and multilingual, but all have English as a common language. Students learning French in the combined degree program in International Studies study language for two years before proceeding to study in France for one year at a French university. I work with a team of three to four French language teachers in Australia, and also travel to meet the French language teachers in France who teach our students when they are on in-country study.

The language pedagogies that I and other teachers in this program use, like those increasingly adopted by teachers elsewhere in Australia and in France, indicate the application of new developments in, and modes of thinking about, approaches to the teaching of language over the last few decades. In the past, the traditional view of language learning involved the teaching of grammar to students so they could best gain access to literature and other products of 'high' culture. Today there is an emphasis on communicative strategies and blended learning. ${ }^{2}$ There is also a greater recognition of the interrelationship between language and society.

In his analysis of the convergences between language and society, Fairclough observes that both have 'an internal and dialectical relationship' with each other (2001: 19). That is, linguistic phenomena are social phenomena, in that language use is determined by sociocultural conventions that are underpinned by the power relations underlying the same conventions. At the same time, language plays a role in constructing, maintaining

\footnotetext{
${ }^{2}$ According to the language and culture subject outlines given to my students, and those studying all the languages taught at my institution: 'The pedagogical key concept we adopt in our curriculum development is Blended Learning which incorporates independent learning and classroom instruction into a coherent program to provide students with a steady progression in language proficiency to enable them to gain full literacy skills in the target language and to equip them with the skills of self-directed learning.'
} 
and changing sociocultural conventions. Fairclough's earlier work on critical discourse analysis (1995) also drew attention to the relationship between discourse and ideology, with the former referring to the actual language used, and the latter to a link between social power and the way it is manifested in language use. This relationship has political implications for how the role of language teachers is understood. Teachers may either contribute to the preservation of normative positions in regard to dominating social practices, or they can challenge them. In the case of the latter, teachers need to promote a class environment that encourages a critical and self-reflective discourse for both students and teachers. This practice needs to be supported by a curriculum and materials that facilitate linguistic and reflective exploration. An awareness of the links between discourse and ideology, and their implications for language teaching and learning, is required whenever introducing new practices, materials or debates into the language classroom. ${ }^{3}$

In terms of the relationship between the French-language learning classroom and formal French language policies emanating from France, students should be given the opportunity to understand and discuss the implications that such language policies have on the language, and on their own learning. Students need to reflect on what language authorities desire of the French language and its speakers, and how language is spoken and written in French society. An examination of some of the teaching material used in the French language curriculum at my institution indicates that debates about the feminisation of professional titles and the use of English terms in French are neither developed nor detailed in that material. ${ }^{4}$ Much of the published teaching material used in French tertiary institutions is written and printed in France, though some textbooks have been written locally in Australia, and others have been produced in Frenchspeaking countries like Canada. In such texts a great deal of the cultural and social content about language usage is therefore influenced by what is happening in France. From what I have experienced and observed, it is thus left to the teacher to explain to students the discrepancies between the official use of professional titles and the realities

\footnotetext{
${ }^{3}$ Similar observations have been developed by De Vincenti, Giovanangeli and Ward (2007) on how the role of the language teacher is understood in today's teaching and learning context.

${ }^{4}$ Recently published textbooks used in beginner and intermediate levels, such as Campus 1\&2 (Girardet \& Pécheur 2002a, 2002b), Forum 2 (Baylon et al. 2002), Connexions 1\&2 (Mérieux \& Loiseau 2004a, 2004b), Studio 60 (Lavenne et al 2001), Studio100 (Lavenne et al 2002), Taxi 1 (Capelle \& Menand 2003) and Rond Point 2 (Flumian et al 2005), were some of the material I considered in making this observation.
} 
of feminine versions slowly creeping into everyday language usage. I have also noticed that explaining the dilemmas of the feminine versus the masculine debate often frustrates students because they are left with the burden of having to make their own choices when, in reality, they want to understand the correct way of using the language. Making students aware of the situation in France is a step closer to helping them resolve how to feminise professional titles, despite the fact that answers are not readily provided in their textbooks. Also, making students aware of guides in current circulation and written to help the French themselves negotiate these debates and linguistic changes, such as the Femme j'écris ton nom noted earlier, is a way of making these choices easier for students.

The use of English words in French is more problematic. The feminisation of professional titles has legible support from political spheres as women take on increasingly important roles in the workplace. Language reflects this change through the appearance of new feminine forms for professional titles, and the publication of guides about how to use those titles. However, defending the French language against the use of English is seen by some critics as the local 'defence against global linguistic monoculture inherent in the spread of English' (Sonntag 2003: 47). Politicians such as the former Minister of Culture under President Mitterrand and Socialist deputy leader, Jack Lang, have written papers on how globalisation, and its connection to US capitalism, is creating a global monoculture against which France must defend itself (Sonntag 2003: 46). Thinkers like Lang associate language with the need to oppose global English hegemony.

As a teacher I am faced with the dilemma of choosing whether or not to encourage the use of French whenever possible, and in this way join or reject the fight to protect the French language. After all, prominent figures like Lang, and institutions like the Académie française, stress this is the right thing to do. Or do I simply explain to students that English words creep into French and encourage them to look at how this is happening, for example, by studying French radio podcasts or blogs written by French speakers in France that provide examples of English loan words in French structures. The assignments I receive from my students while on in-country studies in France, and that ask students to reflect on contemporary social change in that country, confirm to me that these structures do confront students. One assignment I received recently, on the 
use of public space within a particular French city and unrelated to the use of English in French, contained an appendix with interviews the student had conducted in the street with young French speakers. One interview alone showed that English terms such as le street, le skate, les spots, and l'aspect underground were happily integrated into French sentences. If I were to teach these terms to my language students, would I then be encouraging the use of English in French?

I tend to agree with the linguist Henriette Walter (2001) who believes that French is not threatened by English. Some words evolve, while other words are borrowed only for a certain time and then fall out of fashion. She also makes a point of listing examples of French terms used in the English language. For Walter words have been travelling from language to language for centuries (2001: 15). There needs to be room in the language classroom to examine and to explore these sorts of interchanges. In the first few pages of a beginner language textbook currently used in our language program, the term adresse électronique (email) is the only option given for the term email, despite the fact that the French also use the English word 'email' extensively (Mérieux et al 2004: 24). The onus falls on the teacher to explain that both terms are acceptable in everyday French idiom. The teachers I have worked with often speak within a space where they explain: 'here is the French word but you will also see this English term used.'

\section{Concluding Comments}

This essay identifies the difficulties that are created within a language classroom when conflicting information exists between the realities of French language usage and the desires on the part of individuals and institutions either to police the language from corrupting influences or to act as agents in its inevitable evolution. A teacher may choose to explore the French language by presenting it in a desired pure form, closely aligned to the way the Académie française or French politicians would like it to be taught. The reality, however, indicates that students of the French language are confronted with a language that is evolving in everyday speech in order to meet the challenges of constant sociocultural change.

Two areas stand out as problematic in the debates over a desired French language and that language's quotidian realities: the feminisation of professional titles; and the inclusion of English terms in the French language. Dealing with these issues poses challenges for language learners; but the ideal place for confronting these challenges is 
within the space of the language classroom where language desires and realities can be discussed. Recognising the interrelationship between language and society is crucial; the language classroom space is a place where linguistic structures and policies are able to meet. For students studying French, this space is a venue in which to raise awareness about the sociocultural aspects of language and to develop discussion about, and awareness of, the implications that language policies have on French as it is lived, and taught and learned. Indeed, I have argued here that excluding from the classroom debate over language policies, and the defenders of the French language, risks marginalising the linguistic reality of France today. It is essential for French language teachers to take a critical approach towards material and activities in order to give students the framework to explore the sociocultural and political ramifications of the French language and its evolution.

This paper, then, is a preliminary meditation on those ramifications. Some areas for further elaboration include how to develop an enquiry-based approach in the French language curriculum using materials and activities that allow students to explore how language policies affect the French language while also developing their language learning skills. As technology is increasingly used in language classrooms, it would be worth exploring the quotidian evolution of the French language through such authentic material as blogs, podcasts, advertisements and virtual spaces (for example, Second Life), and thus better identify how desired language policies diverge from the realities of the French language in all its registers. In addition to the activities that promote language learning, the classroom should be a space that investigates the language debates taking place in France. Discussions on whether French singers can choose English or French in the Eurovision Song Contest, or whether national French companies can be taken to court for imposing the use of English in the workplace instead of French, must take place in classrooms wherever French is taught. 


\section{Reference List}

Adamson, R. 2007, The Defence of the French. A Language in Crisis?, Multilingual Matters, Clevedon. Baylon, C. et al. 2002, Forum 2, Hachette FLE, Paris.

Becquer, A., Cerquiglini, B. \& Cholewka, N. (eds) 1999, Femme j'écris ton nom. Guide d'aide à la féminisation des noms de métiers, titres, grades et fonctions, Institut national de la langue française, Paris.

Bremner, C. 2006, 'Chirac contre l'anglais,' Times Online, 24 March. Online, available: http://timescorrespondents.typepad.com/charles_bremner/2006/03/chirac_contre_1.html (Accessed 8 October 2007).

Bremner, C. 2008, 'French drop le pop in search of Eurovision win,' Times Online, 16 April. Online, available: http://www.timesonline.co.uk.tol.news/world/europe/article 3754191.ece (Accessed 18 April 2008).

Brick, N., \& Wilks, C. 1994, 'Et Dieu nomma la femme: observations sur la question de la féminisation des noms d'agent er sur les désignations d'Edith Cresson dans la presse,' French Language Studies, vol. 4, no. 2 (September), 235-39.

Brick, N., \& Wilks, C. 2002, 'Les partis politiques et la féminisation des noms de métier,' French Language Studies, vol. 12, no. 1 (March), 43-53.

Capelle, G. \& Menand, R. 2003, Taxi 1, Hachette FLE, Paris.

Conrick, M, 2002, 'Language Policy and Gender Issues in Contemporary France,' in French In and Out of France: Language Policy, Intercultural Antagonisms and Dialogue, (ed.) K. Salhi, Peter Lang, New York. 205-35.

De Certeau, M. Julia, D. \& Revel, J. 2002, Une politique de la langue, Gallimard, Paris.

De Vincenti, G., Giovanangeli A. and Ward, R. 2007, 'The Queer Stopover: How Queer Travels in the Language Classroom,' Electronic Journal of Foreign Language Teaching, vol. 4, suppl. 1, 58-72. Online, available: http://e-flt.nus.edu.sg/v4sp12007/ward.pdf (Accessed 29 July 2008).

Fairclough, N. 1995, Critical Discourse Analysis: The Critical Study of Language, Harlow, Longman.

Fairclough, N. 2001, Language and Power, $2^{\text {nd }}$ ed, Harlow, Longman.

Flumian, C. et al. 2005, Rond Point 2, Presses universitaires de Grenoble, Grenoble.

Gilder, A. 1993, Et si l'on parlait français? Essai sur une langue universelle, le Cherche Midi éditeur, Paris.

Girardet, J \& Pécheur, J. 2002a, Campus Niveau 1, CLE international, Paris.

Girardet, J \& Pécheur, J. 2002b, Campus Niveau 2, CLE international, Paris.

Houdebine-Gravaud, A-M. 1999, 'Femmes/langue/féminisation: Une expérience de politique linguistique en France,' Nouvelles questions féministes, vol. 20, no. 1, 23-50.

Lang, J. 2000, 'L'amour de Babel,' in Langues : une guerre de mort, Panoramiques, Corlet, Courbevoie, 128-30.

Lavenne, C. et al, 2001, Studio 60, Didier, Paris.

Lavenne, C. et al. 2002, Studio 100, Didier, Paris.

Magnant, A. 2000, 'Le français est-il encore une langue internationale ?,' in Langues: une guerre de mort, Panoramiques, Corlet, Courbevoie, 124-27.

Mérieux, R. \& Loiseau, Y. 2004a, Connexions. Méthode de français, Niveau 1, Didier, Paris.

Mérieux, R. \& Loiseau, Y. 2004b, Connexions. Méthode de français, Niveau 2, Didier, Paris.

Ministère des Affaires Etrangères. 2007, Francophony/French Language. Last update July. Online, available: http://diplomatie.gouv.fr/en/france-prioties_1/francophony-frenchlanguage_1113/francophony_1932/prsentation_4278/index.html\#sommaire_2 (Accessed 5 October 2007).

Réau, L. 1938, L'Europe française au siècle des lumières, Albin Michel, Paris.

Rey-Debove, J. 1999, 'Féminisation de la langue: une affaire d'usage,' Le Français dans le monde, Mai/Juin, no. 304, 59-60.

Sonntag, S. K. 2003, The Local Politics of Global English. Case Studies in Linguistic Globalization. Lexington Books, Lanham.

Vandendorpe, C. 1995, 'Du fondamentalisme linguistique ou de la tentation de rectifier la pensée par le langage,' Discours social. L'Esprit de censure, vol. 7, no. 1-2, 135-52.

Walter, H. 2001, Honni soit qui mal y pense. L'incroyable histoire d'amour entre le français et l'anglais, Robert Laffont, Paris. 